\title{
PENGARUH KESADARAN MEREK, NILAI PRODUK DAN KEUNIKAN MEREK TERHADAP LOYALITAS MEREK UNIQLO DI BATAM
}

\author{
Enrico Yola dan Louis Utama \\ Tarumanagara University Faculty Economics And Business, Jakarta \\ Email: Enrico.115160292@stu.untar.ac.id
}

\begin{abstract}
The purpose of this study is to test whether brand awareness can influence brand loyalty, product value can affect brand loyalty, brand uniqueness can affect brand loyalty. Data analysis conducted in this study using SEM (Structural Equation Modeling), with the PLS measuring instrument. The sample was selected using convenience sampling method totaling 70 respondents. The results of this study are Brand Awareness, Product Value and Brand Uniqueness that are positive and significant towards brand loyalty.
\end{abstract}

Keywords: Brand Awareness, Perceived Value, Brand Uniqeness, Brand Loyalty.

Abstrak: Tujuan dari penelitian ini adalah untuk menguji apakah kesadaran merek dapat loyalitas merek, Nilai produk dapat mempengaruhi loyalitas merek, Keunikan merek dapat mempengaruhi loyalitas merek,. Analisis data yang dilakukan pada penelitian ini menggunakan SEM (Structural Equation Modeling), dengan alat ukur PLS. Sampel dipilih menggunakan metode convenience sampling berjumlah 70 responden. Hasil penelitian ini adalah Kesadaran Merek, Nilai Produk dan Keunikan Merek positif dan signifikan terhadap loyalitas merek.

Kata Kunci: Kesadaran, Nilai, Keunikan, Loyalitas.

\section{LATAR BELAKANG}

Pada zaman sekarang, fast fashion telah menjadi hal yang penting dalam gaya hidup yang diminati oleh masyarakat. Fast fashion bertumbuh dengan cepat dari perusahaan tekstil yang terkenal dan dipercaya yang memiliki model dan konsep yang berbeda yang membuat perubahan dalam industri pasar dan global. Ide bisnis dibalik fast fashion brand selalu didasarkan pada fashion, kualitas dan harga yang tepat. Fast fashion diartikan sebagai model bisnis yang mana memberikan trend fashion terkini beserta respon yang lincah dengan permintaan konsumen harga wajar. Perusahaan tesktil menggunakan metode yang memotong biaya untuk menurunkan biaya produksi dan memaksimalkan keuntungan perusahaan. Konsep bisnis dari merek-merek fast fashion selalu berlandasan trerhadap style fashion, kualitas bersaing dengan harga jual yang tepat.

Fast fashion memiliki konsep tren yang digunakan industri tekstil secara global dan pertumbuhan fast fashion sedang terjadi secara cepat dan sekarang adalah waktu yang tepat untuk meneliti dan menguji sikap konsumen dari fast fashion. Fast fashion tidak akan meledak seperti sekarang dalam gaya hidup konsumen yang membutuhkan industri mode untuk beradaptasi dengan cepat terhadap tren dan menawarkan lebih banyak pilihan produk. 


\section{KAJIAN TEORI}

Berdasarkan tujuan penelitian yang sudah tertulis diatas, penelitian ini dapat disimpulkan dengan Theory of Reasoned Action (TRA) menjelaskan tentang berubahnya sebuah perilaku yang dihasilkan dari niat perilaku, dan niat perilaku yang telah dipengaruhi oleh norma sosial dan sikap individu terhadap perilaku (Eagle, Dahl, Hill, Bird, Spotswood, \& Tapp, 2013, hal. 123). Niat seseorang untuk melakukan suatu perilaku menentukan akan dilakukan atau tidak dilakukannya perilaku tersebut. Niat untuk melakukan atau tidak melakukan sesuatu dengan perilaku tertentu dipengaruhi oleh dua penentu dasar, berhubungan dengan sikap (attitude towards behavior) dan yang lain berhubungan dengan pengaruh sosial yaitu norma subyektif (Ajzen, 1980). Theory of Reasoned Action menjelaskan tahapan-tahapan manusia melakukan perilaku. Pada tahap yang pertama, perilaku (behavior) dapat diasumsikan ditentukan oleh niat (intention). Pada tahap berikutnya, niat dapat dijelaskan dalam bentuk sikap terhadap perilaku (attitudes toward the behavior) dan norma subyektif. Tahap-tahap selanjutnya ,dipertimbangkan sikap dan norma subyektif dalam bentuk kepercayaan tentang konsekuensi terhadap perilakunya dan ekspektasi normatif dari orang yang relevan. Dalam upaya mengungkapkan pengaruh sikap dan norma subjektif terhadap niat untuk dilakukan atau tidak dilakukannya perilaku, Theory of Reasoned Action dilengkapi dengan keyakinan Dikemukakannya bahwa sikap berasal dari keyakinan terhadap perilaku sedangkan norma subjektif berasal dari keyakinan normatif .

Kesadaran Merek. Kesadaran yang dirasakan oleh manusia terjadi saat membangun ekuitas merek dan untuk meningkatkan merek pada pola pikir pelanggan sebagai pedoman untuk membuat perumusan strategi. Kesadaran merek mengacu pada "kemampuan pembeli potensial untuk mengenali atau mengingatnya sebuah merek adalah anggota dari kategori produk tertentu" (Aaker, 1991).

Kemampuan pembeli untuk mengetahui sebuah merek terkait dengan kekuatan kehadiran suatu merek dibenak konsumen dan biasanya dapat diukur dengan kemampuan konsumen untuk mengenali suatu produk saat mereka melihat produk tersebut dan kemampuan konsumen untuk mengingat nama sebuah merek (Aaker, 1996; Keller, 1993).

Nilai Produk. Nilai-nilai yang dirasakan pada pelanggan dapat didefinisikan sebagai penilaian dari keseluruhan pelanggan atas utilitas berbasis merek pada nilai yang diterima seperti kualitas atau kepuasan pelanggan terhadap suatu produk dan apa yang dapat mereka berikan seperti harga yang dapat diterima oleh pelanggan (Netemeyer et al., 2004).

Nilai yang dirasakan melibatkan trade-off dari "apa yang saya dapatkan" (yaitu manfaat fungsional dan emosional) untuk "apa yang saya berikan" (yaitu waktu, uang, dan usaha) (Kirmani \& Zeithaml, 1993; Netemeyer et al., 2004). Kepribadian merek dapat didefinisikan tentang karakteristik atau cirikhas yang ditawarkan oleh merek dari persepsinya konsumen (Aaker, 1991; Keller, 1993).

Keunikan Merek. Keunikan dari sebuah merek dapat diketahui sejauh mana seorang konsumen merasakan nilai yang berbeda pada suatu merek dengan merek yang lain (Netemeyer et al., 2004). Jika sesuatu merek tidak dianggap berbeda atau kurang inovasi maka akan mengalami kesulitan dalam menarik perhatian dan komitmen konsumen.

Keunikan dapat diperlihatkan melalui penerimaan dan memiliki perbedaan produk yang berbeda dari yang pesaing. Dari pengertian keunikan menurut para ahli, maka dapat disimpulkan bahwa keunikan adalah suatu produk yang memiliki ciri khas tersendiri yang bisa membuat konsumen merasa bahwa suatu produk berbeda dengan produk lainnya (Lynn, 2007). 
Kaitan antar variable. Keterkaitan Kesadaran merek terhadap Loyalitas merek. Dalam hal yang sangat kompetitif di bidang bisnis yang terjadi dilingkungan saat ini, Langkah pertama adalah dengan cara berkonsentrasi pada manajemen merek dan mencari strategistrategi untuk meningkatkan kesadaran konsumen yang memperkuat merek. Ketika konsumen tidak percaya atau tidak yakin pada suatu produk, merek dapat digunakan untuk memberi tahu mereka tentang posisi produk dan memastikan bahwa produk dapat dipercaya.

Ketidakpastian yang dirasakan oleh konsumen berkurang dapat menurunkan biaya informasi dan resiko yang dirasakan oleh konsumen tetapi meningkatkan harapan konsumen pada suatu merek. Secara mendunia, pertumbuhan dari suatu merek dapat menggunakan berbagai cara dengan contohnya media seperti internet,tv,handphone dan majalah dab liputan mode mereka telah berkontribusi pada peningkatan kesadaran pelanggan di kalangan konsumen muda (Sasmita dan Suki, 2015). Kesadaran merek memengaruhi konsumen persepsi tentang produk fast fashion dan preferensi, keterikatan dan loyalitas merek mereka menuju merek fashion cepat.

\section{Keterkaitan Nilai produk terhadap Loyalitas merek}

Nilai yang dirasakan berada pada level yang lebih tinggi dari abstraksi daripada atribut atau manfaat merek apa pun. Nilai yang dirasakan konsumen melibatkan penilaian konsumen secara keseluruhan atas atribut fungsional, pengalaman, atau simbolik merek dan manfaat dalam kaitannya dengan biaya dan upaya yang dilakukan oleh konsumen (Netemeyer et al., 2004).

Apabila seorang konsumen yang mempunyai persepsi nilai yang tinggi dapat melakukan pembelian ulang dimasa mendatang yang akan memunculkan loyalitas merek pada produk tersebut. Sehingga nilai tersebut merupakan hal yang penting dalam pemahaman perilaku konsumen, karena persepsi konsumen tentang value berpengaruh terhadap keputusan pembelian mereka yang pada akhirnya mampu menciptakan loyalitas merek.

Nilai pelanggan sebagai penilaian keseluruhan konsumen terhadap utilitas sebuah produk berdasarkan persepsinya terhadap apa yang diterima dan apa yang diberikan (Tjiptono, 2014). Nilai pelanggan adalah ikatan emosional yang terjalin antara pelanggan dan produsen setelah pelanggan menggunakan produk atau jasa yang dihasilkan pemasok tersebut dan mendapati bahwa produk bersangkutan memberikan nilai tambah (Butz \& Goodstein,2014, p.308).

\section{Keterkaitan Keunikan merek terhadap Loyalitas merek}

Persepsi konsumen dari sebuah merek didorong oleh rasa kebutuhan dan pengetahuan mereka terhadap keunikan dari sebuah merek yang diturunkan dari pengalaman pribadi (Keller, 2010). Model Fast fashion seperti merek Zara, Uniqlo dan H\&M memiliki kekuatan tersendiri seperti keunikan yang mereka tawarkan kepada masyarakat pada produk mereka (Park \& Sternquist, 2008). Pakaian dari Fast fashion memenuhi kebutuhan konsumen melalui keunikan yang mereka tawarkan yang berbeda dengan merek lain dan itu dapat mengembangkan dan meningkatkan citra diri serta citra sosial seseorang (Shen et al., 2014).

Fast fashion telah meningkatkan pangsa pasar fashion dan meningkatkan kepercayaan pada konsumen. Konsumen mencari fast fashion terbaru yang unik produk karena fakta bahwa mereka menyediakan barang paling trendi dan menciptakan keunikan di pasar mode dengan memproduksi kelangkaan dalam jumlah kecil (Barnes \& Lea-Greenwood, 2006; Shen et al., 2014). Terlepas dari bagaimana bentuknya, jika suatu merek dianggap unik, itu dapat meningkatkan kesadaran merek konsumen dan niat membeli dan dapat memerintahkan harga premium di pasar. 
Berdasarkan kerangka pemikiran diatas, maka hipotesis pada penelitian ini dapat dilihat pada Gambar dibawah ini

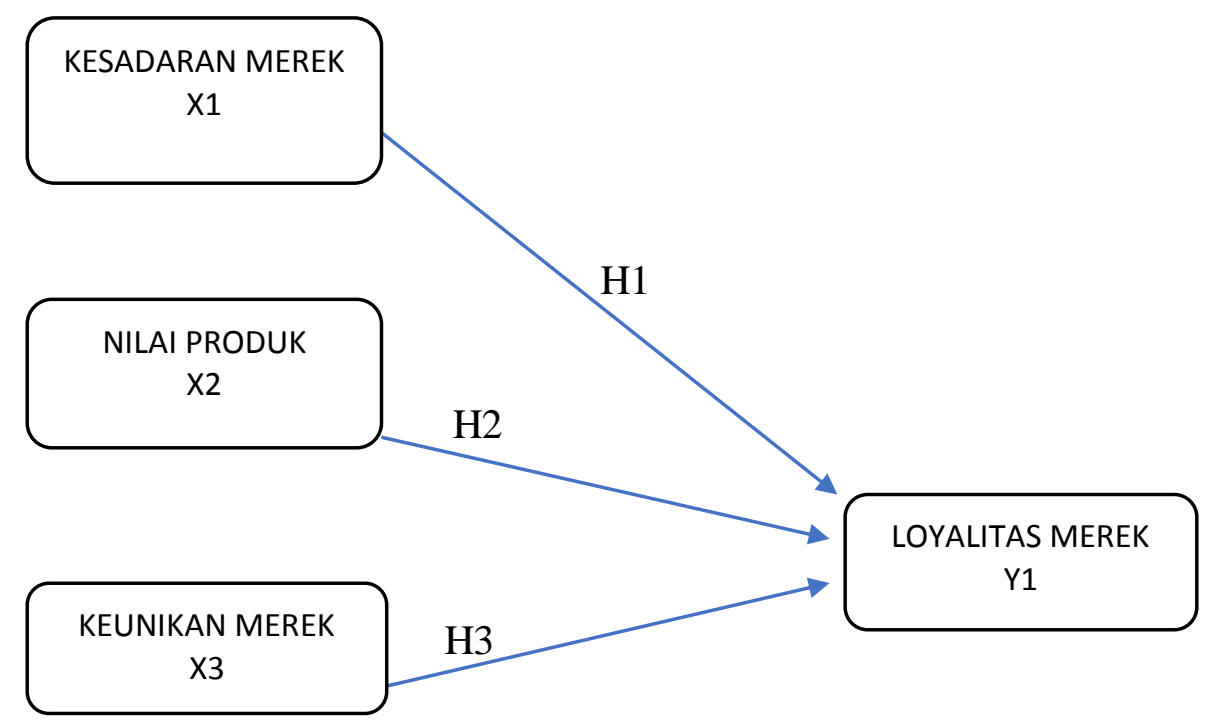

Gambar 1. Model Penelitian

Berdasarkan Gambar 2.1, maka penelitian ini memiliki hipotesis sebagai berikut:

H1: Kesadaran merek mempengaruhi Loyalitas merek Uniqlo di Batam.

H2: Nilai produk mempengaruhi Loyalitas merek Uniqlo di Batam.

H3: Keunikan merek mempengaruhi Loyalitas merekUniqlo di Batam.

\section{METODOLOGI}

Penelitian ini menggunakan penelitian deskriptif cross sectional. Sampel diambil menggunakan metode nonprobability sampling dengan menggunakan teknik convenience sampling. Hal ini dilakukan karena memiliki kriteria atau ciri-ciri tertentu untuk pengambilan sampel. Terdapat 70 responden dalam penelitian ini, semua pernah membeli atau menggunakan produk Uniqlo.

Pengukuran variabel-variabel dalam penelitian ini mengacu pada penelitian sebelumnya antara lain sebagai berikut:

\begin{tabular}{|c|c|c|}
\hline Variabel & Indikator & Acuan \\
\hline Kesadaran Merek & 3 item & $\begin{array}{c}\text { (Buil et al. 2008), (Husnawati } \\
\text {,2017) \& (Tong \&Hawley, } \\
\text { 2009) }\end{array}$ \\
\hline Nilai Produk & 3 item & $\begin{array}{c}\text { (Netemeyer et al. ,2004), } \\
\text { (Aaker ,1996) \& (Su \& Chang } \\
\text {,2017) }\end{array}$ \\
\hline Keunikan Merek & 3 item & $\begin{array}{c}\text { (Netemeyer et al. ,2004) \& (Su } \\
\text { \& Chang, 2017) }\end{array}$ \\
\hline Loyalitas Merek & 3 item & $\begin{array}{c}\text { (Buil et al.,2008),\& (Su \& } \\
\text { Chang, 2017) }\end{array}$ \\
\hline
\end{tabular}




\section{HASIL UJI STATISTIK}

Hasil pengujian validitas konvergen dalam penelitian ini dapat dikatakan valid dalam penelitian ini, nilai AVE yang diperoleh bernilai lebih besar dari $0,5(>0,5)$ serta nilai loading factor dari setiap indikatornya lebih besar dari $0,7(>0,7)$ namun lebih besar dari 0,6 $(>0.6)$ masih dapat diterima. Hasil uji reliabilitas dalam penelitian ini dikatakan reliabel berdasarkan hasil analisis dengan menggunakan pendekatan Cronbach's Alpha maupun Composite Reliability pada item untuk setiap variabel yang lebih dari 0,6. Sedangkan, discriminant validity terdiri dari analisis fornell-larckerdan cross loading. Hasil yang diperoleh dalam penelitian ini menunjukkan bahwa nilai yang diperoleh telah memenuhi syarat cross-loadings dan fornell-larcker, namun variabel brand loyalty tidak memenuhi syarat, karena mempunyai nilai konstruk lebih kecil dari pada kolerasi dengan variabel-variabel lainnya .

$\mathrm{R}^{2}$ berfungsi untuk mengetahui besarnya hubungan atau kontibusi antar variabel-variabel independen dalam dalam penelitian ini yaitu kesadaran mrek, nilai produk dan keunikan merek terhadap variabel dependennya loyalitas merek. Nilai $R$-square sebesar 0,684, dapat dikatakan mempunyai pengaruh yang substansial. Selanjutnya, hasil pengujian $\mathrm{Q}^{2}$ menunjukan nilai sebesar 0,529 nilai predictive relevance $\left(\mathrm{Q}^{2}\right)$ dalam penelitian ini lebih besar dari 0 (nol) dan dapat dikatakan relevan.

Hasil analisis data secara singkat dapat dilihat pada Tabel 1.

Tabel 1

Hasil Pengujian Hipotesis

\begin{tabular}{lccc}
\multicolumn{1}{c}{ Variabel } & Path Coefficient & t-statistics & p-values \\
\hline Kesadaran Merek => Loyalitas Merek & 0,478 & 4,375 & 0,000 \\
\hline Nilai Produk => Loyalitas Merek & 0,238 & 2,140 & 0,049 \\
\hline Keunikan Merek => Loyalitas Merek & 0,236 & 1,973 & 0,033
\end{tabular}

Berdasarkan pada hasil dari pengujian bootstrapping yang ditampilkan pada Tabel 1 di atas, maka dapat disimpulkan bahwa hasil pada variabel kesadaran merek terhadap loyalitas merek yang positif dan signifikan karena mempunyai nilai 0,478 , variabel nilai produk terhadap loyalitas merek juga memiliki hasil yang positif dan signifikan mempunyai nilai 0,238 dan variabel keunikan merek terhadap loyalitas merekmempunyai hasil yang signifikan dan positif karena mempunyai nilai 0,236. Pengujian goodness of fit (GoF), hasil perhitungannya menyatakan model yang digunakan dalam penelitian ini memiliki nilai GoF sebesar 0,7758 dan perhitungan dilakukan dengan cara manual. model yang digunakan dalam penelitian ini memiliki kecocokan yang tinggi karena GoF lebih besar dari 0,36 $(>0,36)$ (Wetzels et al. , 2009).

\section{DISKUSI}

Pada pengujian hipotesis pertama, variabel kesadaran merek terbukti dapat memprediksi secara positif loyalitas merek Uniqlo di Batam. Hasil tersebut terlihat melalui nilai t-statistics dari kesadaran merek terhadap loyalitas merek yaitu sebesar 4,375 yang lebih besar dari batas minimum yaitu 1,96, dan juga nilai p-values sebesar 0,000 yang lebih kecil dari batas minimumnya yaitu $\alpha=0,05$. Atas hasil dari pengujian hipotesis tersebut, dapat disimpulkan bahwa $H 1_{a}$ tidak ditolak dan penelitian ini didukung oleh penelitian sebelumnya yang dilakukan oleh Su dan Chang (2017), dapat disimpulkan bahwa kesadaraan konsumen terhadap merek suatu produk dapat mendorong seorang konsumen untuk loyal terhadap produk 
suatu merek dan melakukan pembelian produk tersebut terus menerus dengan jangka waktu yang panjang.

Pada pengujian hipotesis kedua, Berdasarkan hasil di atas, variabel nilai produk terbukti dapat memprediksi secara positif loyalitas merek Uniqlo di Batam. Hasil tersebut terlihat melalui nilai t-statistics dari brand experience terhadap loyalitas merek yaitu sebesar 2,140 yang lebih besar dari batas minimum yaitu 1,96 , dan juga nilai p-values sebesar 0,049 yang lebih kecil dari batas minimumnya yaitu $\alpha=0,05$. Atas hasil dari pengujian hipotesis tersebut, dapat disimpulkan bahwa $H 1_{a}$ tidak ditolak dan penelitian ini didukung dengan penelitian sebelumnya yang dilakukan bahwa Nilai pelanggan yang lebih baik dibandingkan dengan apa yang pesaing berikan akan membuat pelanggan merasa puas dan pada gilirannya akan mendorong dia untuk setia (Zeithaml, 1988).

Pada pengujian hipotesis ketiga, Berdasarkan hasil di atas, variabel keunikan merek terbukti dapat memprediksi secara positif loyalitas merek Uniqlo di Batam. Hasil tersebut terlihat melalui nilai t-statistics dari brand experience terhadap loyalitas merek yaitu sebesar 1,973 yang lebih besar dari batas minimum yaitu 1,96 , dan juga nilai p-values sebesar 0,033 yang lebih kecil dari batas minimumnya yaitu $\alpha=0,05$. Atas hasil dari pengujian hipotesis tersebut, dapat disimpulkan bahwa $H 1_{a}$ tidak ditolak dan dan penelitian ini didukung dengan penelitian sebelumnya yang dilakukan oleh Su dan Chang (2017), dapat disimpulkan memang produk yang di produksi oleh merek Forever 21 berbeda dari yang lainya atau unik dan keunikan dari produk tersebut dapat menciptakan loyalitas seseorang akan sebuah merek.

\section{PENUTUP}

Dari penelitian ini, dapat diketahui bahwa kesadaran merek dapat memprediksi secara positif dan signifikan terhadap loyalitas merek, nilai produk dapat memprediksi secara positif dan signifikan terhadap loyalitas merek, keunikan merek dapat memprediksi secara positif dan tidak signifikan terhadap loyalitas merek. Peneliti menyarankan, Perusahaan perlu untuk terus berinovasi memberikan nilai produk yang berbeda dalam hal berbelanja. Perusahaan dapat melakukan banyak hal seperti berinovasi terhadap penampilan toko yang lebih menyenangkan pelanggan dibandingkan dengan toko pesaing lainnya. Hal ini akan membuat suasana hati pelanggan menjadi lebih baik ketika berbelanja yang akan mendorong terciptanya pengalaman lain yang menyenangkan sehingga loyalitas pelanggan Uniqlo akan meningkat. Peneliti juga menyarankan untuk meningkatkan kesadaran merek pada pelanggan agar dapat teringat dengan mudah sebuah perusahaan. Dengan meningkatnya kesadaran merek pelanggan, sebuah perusahaan sudah mendapatkan keuntungan yang sangat besar dan dikenali oleh masyarakat.

Peneliti juga menyarankan agar dapat memanfaatkan kesempatan tersebut untuk mengekspansi ruang lingkup topik yang lebih luas dari variabel yang telah diteliti dalam penelitian ini dan juga menggunakan kesempatan berikut untuk melengkapi kekurangan dan memperkuat hasil temuan yang ada dalam penelitian ini.

\section{DAFTAR PUSTAKA}

Aaker, D.A. (1991), Managing Brand Equity: Capitalizing on the Value of a Brand Name, The Free Press, New York, NY.

Aaker dan Keller, 2010, Consumer Evaluation of Brand Extension . Journal of Marketing Vol. 54 (January 1990), 27-41

Algesheimer, et al. (2005), "The Social Influence of Brand Community;Evidence From European Car Clubs", Journal of Marketing, Vol.69, p.19-34. 
Barnes, L., \& Lea-Greenwood, G. (2006). Fast fashioning the supply chain: Shaping the research agenda. Journal of Fashion Marketing and Management: An International Journal, 10(3), 259-271.

Butz, H.E., \& Goodstein, L.D. (2016). Measuring Customer Value: Gaining the Strateguc Advantage, Organizational Dynamic, Vol. 24, pp: 63-77

Carolyn Kisner Lynn Allen Colby. 2007.Therapeutic Exercise, Fifth Edition, (Philadelpia : F.A. Davis Company). Hal 106.

Eagle, L., Dahl, S., Hill, S., Bird, S., Spotswood, F., Tapp, A. (2013). Social Marketing. Pearson Prentice Hall: London

Keller, K. L. (1993): Conceptualizing, Measuring, and Managing Customer-Based Brand Equity. Journal of Marketing, 57 (1), 1-22.

Kirmani, A. and Zeithaml, V.A. (1993), "Advertising, perceived quality and brand image", in Aaker, D.A. and Biel, A. (Eds), Brand Equity and Advertising, Lawrence Erlbaum Associates, Hillsdale, NJ, pp. 143-162.

Netemeyer et.al (2004). Developing and Validationg Measures of Facets of Customer-Based Brand Equity. Journal of Business Research. Vol 57, pp 2009 -224.

Parasuraman, Valarie A. Zeithaml, and Leonard L. Berry. 1988. "SERVQUAL: A Multiple-ItemScaleforMeasuring Consumer Perceptions of Service Quality". Journal of Retailing. Vol 64 (1) pp 12- 37

Park, Do-Hyung, and Sara Kim. 2008. The Effects of Consumer Knowledge on Message Processing of Electronic Word-of-Mouth via Online Consumer Reviews. Electronic Commerce Research and Applications, 7 (4): 399- 410

Sasmita, J. and Suki, N.M. (2015), "Young consumers' insights on brand equity: effects of brand association, brand loyalty, brand awareness, and brand image", International Journal of Retail \& Distribution Management, Vol. 43 No. 3, pp. 276-292.

Shen, fan, zhan, zhao. 2014. A Study of the Perceived Value and Behavioral Intentionsof Chinese Marine Cruise Tourists. Tourism Department, Fudan University, Shanghai, China. Tourism, Leisure and Global Change, volume 1.

Tenenhaus, M, Esposito Vinzi, V., Chatelin, T.M., and Lauro, C., 2005. -PLS Path Modelling\|, Computational Statistics and Data Analysis, 48(1), 159-205

Tjiptono, Fandy. (2014), Pemasaran Jasa - Prinsip, Penerapan, dan Penelitian, Andi Offset, Yogyakarta.

Wetzel, R.G. dan Likens. (1979). Limnological Analyses. London: W.B.Saunders Company.

Woodruff, Robert B. (1997). Customer Value : The Next Source for Competitive Advantage, Journal of the Academy of Marketing Science, Vol. 25, No. 2, 139 - 153.

Yamin, Martinis. 2009. Taktik Mengembangkan Kemampuan Individual Siswa. Jakarta: Gaung Persada Press. 